\title{
Analisis Pendapatan Sistem Pertanian Terpadu Integrasi Padi-Ternak Sapi di Kelurahan Tatae Kecamatan Duampanua Kabupaten Pinrang
}

\author{
Analysis of Income of Integrated Agricultural Systems for Cattle-Paddy Integration In \\ Tatae Village, Duampanua District, Pinrang Regency
}

Muh. Jurhadi Kadir

Prodi Peternakan Fakultas Pertanian Peternakan dan Perikanan

Universitas Muhammadiyah Parepare

Jl. Jenderal Ahmad Yani Km. 6. Parepare 91132

Korespondensi E-mail : mj_kadir@yahoo.co.id

\begin{abstract}
ABSTRAK
Penelitian ini bertujuan untuk menganalisis tingkat pendapatan pertanian terpadu terhadap peningkatan pendapatan petani di Kelurahan Tatae, Kecamatan Duampanua, Kabupaten Pinrang. Sistem pertanian terpadu yang dikaji meliputi usahatani padi-ternak sapi, dan usaha-usaha lain yang berpengaruh terhadap pendapatan rumah tangga petani. Budidaya tanaman padi yang menghasilkan output dapat menjadi input bagi ternak seperti pemanfaatan jerami padi sebagai pakan ternak sapi. Pertanian terpadu ditandai oleh keragaman aktifitas yang tinggi yakni pertanian tanaman pangan, peternakan sapi, usaha kebun, usaha kambing, usaha unggas serta usaha lain yang memberi kontribusi terhadap peningkatan pendapatan petani. Hasil penelitian menunjukkan bahwa perkembangan struktur ekonomi petani yang menerapkan usahatani padi monokultur memberi kontribusi pendapatan sebesar Rp 9.213.550,00 dengan B/C Ratio 1,38 dan petani yang menerapkan usahatani sapi monokultur diperoleh pendapatan sebesar Rp 6.856.166,66 dengan B/C Ratio 0,89, sedangkan usahatani padi-sapi terpadu diperoleh pendapatan sebesar Rp 17.981.726,95 dengan B/C Ratio 1,73. Pertanian terpadu memberi kontribusi berupa saling keterkaitan antara subsistem melalui aliran inputoutput antara tanaman dan ternak. Keterpaduan usahatani ternak dapat memberikan kontribusi terhadap pendapatan ditandai dengan adanya reduksi hasil usaha, sehingga berdampak pada peningkatan pendapatan rumah tangga petani.
\end{abstract}

Kata kunci: Integrasi Padi-Ternak Sapi, Pendapatan, Sistem Pertanian Terpadu

\begin{abstract}
This study aims to analysis the effect of integrated agriculture on increasing farmers' income in Tatae Kelurahan, Duampanua District, Pinrang Regency. The integrated farming system studied includes rice-cattle farming, and other businesses that affect the household income of farmers. Rice cultivation that produces output can be an input for livestock such as the use of rice straw as cattle feed. Integrated agriculture is characterized by a high diversity of activities namely food crop farming, cattle ranching, garden business, goat business, poultry business and other businesses that contribute to increasing farmer's
\end{abstract}


income. The results showed that the development of the economic structure of farmers who apply monoculture rice farming contributes an income of $\mathrm{Rp}$ 9,213,550.00 with a B/C Ratio of 1.38 and farmers who apply a monoculture cattle farming receive an income of $\operatorname{Rp} 6,856,166.66$ with B/C Ratio of 0.89 , while integrated rice-cattle farming obtained income of $\mathrm{Rp} .17,981,726.95$ with a B/C Ratio of 1.73. Integrated agriculture contributes in the form of interrelations between subsystems through input-output flows between plants and livestock. The integration of livestock farming can contribute to income marked by the reduction in operating results, so that it has an impact on increasing farm household income.

Keywords: Paddy-Cattle Integration, Income, Integrated Agricultural Systems

\section{PENDAHULUAN}

Pembangunan pertanian sekarang dan masa yang akan datang dihadapkan pada berbagai tantangan yang harus segera diantisipasi. Tantangan tersebut diantaranya adalah pemenuhan kecukupan pangan, pasar global, peningkatan kesejahteraan masyarakat pedesaan, penyediaan lapangan kerja, kelestarian sumber daya alam serta perubahan iklim global.

Didunia pertanian tantangan yang sering dihadapi di tingkat petani umumnya usaha pertanian masih bersifat parsial (per subsektor), sehingga petani sebagai pelaku usahatani dikelompokkan menjadi petani tanaman pangan, hortikultura, ikan, ternak, dan perkebunan (Hasan dan Safaruddin, 2012). Hal tersebut membawa dampak negatif terutama bagi para petani yang hanya memiliki atau menggarap lahan usaha sempit $(0,1-0,5$ ha) karena tidak dapat memanfaatkan aset yang dimilikinya secara optimal. Sebagai contoh, lahan sawah masih dipandang sebagai media untuk memproduksi bahan pangan berupa padi dan palawija saja. padahal melalui pemanfaatan teknologi tepat guna lahan sawah selain dapat dimanfaatkan untuk usahatani tunggal (single commodity approach), juga dapat dimanfaatkan untuk usahatani terpadu (integrated commodities farming system approach).

Keterpaduan usahatani tanaman ternak menempati posisi penting dan strategis untuk dilaksanakan yang secara kontinyu memerlukan dukungan ilmu pengetahuan dan teknologi yang sesuai dengan kondisi fisik lingkungan dan sosial ekonomi petani setempat. Lembaga penelitian dan perguruan tinggi telah menghasilkan dalam jumlah besar informasi dan teknologi maju, namun sampai saat ini yang dimanfaatkan oleh petani jumlahnya masih terbatas. Untuk itu diperlukan kebijakan, langkah-langkah, dan tindak lanjut yang konkret 
untuk mempercepat transfer dan adopsi informasi teknologi oleh petani. Perkembangan teknologi dan informasi tentunya berdampak pada produktivitas usahatani ternak.

Pengembangan tenak sapi dengan memanfaatkan jerami sebagai pakan ternak yang dapat menghasilkan kotoran (feses) sebagai input pertanian cukup besar. Hal ini didukung pernyataan Novitri dkk., (2019) bahwa seekor sapi dapat menghasilkan kompos 2-3 kh/hari yang dapat digunakan sebagai pupuk tanaman. Masih tersedianya lahan dan melimpahnya limbah pertanian seperti jerami padi, jerami jagung dan limbah pertanian lainnya. Limbahlimbah pertanian ini dapat dimanfaatkan oleh ternak sapi sebagai pakan, sedangkan ternak akan menghasilkan produk bernilai ekonomis tinggi yakni pupuk organik yang dapat menjaga kesuburan tanah. Hal ini sejalan pendapat Usman dkk., (2017), bahwa kotoran sapi mampu memperbaiki struktur dan ketersediaan unsur hara tanah. Selanjutnya pemanfaatan limbah pertanian sebagai pakan dapat meningkatkan produksi ternak sapi. Menurut Wachirapkom et al., (2015), pemberian tongkol jagung dapat memperbaiki pemasukan nutrisi, produksi susu dan pertumbuhan sapi perah.

Pendapatan petani masih rendah baik secara nominal maupun secara relatif dibandingkan dengan sektor lain. Oleh karena itu melalui konsepsi pertanian terpadu pola integrasi padi-ternak sapi, maka diharapkan mampu menumbuhkan sektor pertanian sekaligus sektor peternakan untuk meningkatan pendapatan nasional dengan tetap mempertahankan kelestarian sumberdaya.

\section{MATERI DAN METODE}

\section{Materi Penelitian}

Penelitian ini menggunakan pendekatan deskriptif kuantitatif dengan mengkaji sistem pertanian yang dilaksanakan secara monokultur dan pertanian yang dilaksanakan secara terpadu. Dilaksanakan di Kelurahan Tatae Kecamatan Duampanua Kabupaten Pinrang Propinsi Sulawesi Selatan. Data yang dibutuhkan dalam penelitian ini adalah data primer dan data sekunder.

\section{Metode Pengumpulan dan Analisis Data}

Metode pengumpulan data meliputi: observasi, wawancara berstruktur, wawancara bebas dan metode dokumen. Menggunakan 90 responden dengan karakterisitik umur 25 hingga 65 tahun, tingkat pendidikan Sekolah Dasar hingga Sekolah Menengan Atas dengan pengalaman bertani antara 14 hingga 27 tahun. Data ditabulasi dan dianalisis dengan 
menggunakan metode analisis deskriptif dan analisis tingkat pendapatan petani/peternak. Dilanjutkan dengan Uji hubungan dengan menggunakan uji t test.

\section{HASIL DAN PEMBAHASAN}

Kecamatan Duampanua yang berada di Sebelah Utara Kabupaten Pinrang memiliki luas wilayah 29,189 ha dan berada pada ketinggian 0,1-100 meter dari permukaan laut (dpl), daerah ini tergolong daerah yang beriklim tropis dengan kelembaban dan temperatur berfluktuasi setiap tahun. Tipe iklim daerah ini menurut Sebubdi Ferguson termasuk Tipe A dan Tipe B. Daerah ini termasuk daerah basah. Dengan iklim tipe A dan tipe iklim B maka sangat menguntungkan oleh karena ketersediaan komoditi tanaman pangan, termasuk ternak dan aneka tanaman sepanjang tahun dapat tersedia.

Kondisi sosial ekonomi petani di Kelurahan Tatae sangat penting diketahui karena sangat mempengaruhi baik dalam adopsi maupun teknologi yang akan diterapkan di tingkat petani. Kondisi sosial ekonomi ini dapat dilihat berdasarkan variabel seperti umur, tingkat pendidikan, pengalaman usaha, jenis usaha, status pekerjaan dan status pemilikan lahan. Kondisi sosial ekonomi petani dilokasi penelitian meliputi tingkat umur, pendidikan, pengalaman usaha, jumlah tanggungan, dan tenaga kerja produktif.

\section{Umur Petani}

Produktifitas kerja berhubungan erat dengan umur seseorang, asumsi bahwa produktivitas dapat meningkat seiring dengan umur produktif reponden. Ditingkat petani tentunya umur berhubungan dengan tenaga yang dikeluarkan untuk menghasilkan pendapatan dalam bidang usahatani dan ternak mereka.

Tingkatan umur responden memperlihatkan bahwa umur produktif petani baik monokultur padi, monokultur sapi dan padi-sapi terpadu adalah antara 36-40 tahun yaitu 8, 11, dan 9 responden, sedangkan jumlah paling rendah tingkat umur produktif monokultur padi, monokultur sapi, dan padi-sapi terpadu adalah adalah 51-55 tahun. Terlihat adanya variasi umur produktif petani dikarenakan daerah ini dulunya merupakan daerah tujuan transmigrasi sehingga terdapat variasi umur produktif.

\section{Pendidikan}


Jenjang pendidikan yang dimaksud dalam penelitian ini adalah jenjang formal yang ditempuh oleh responden mulai dari tingkat dasar, sekolah tingkat pertama, sekolah menengah atas dan tingkat perguruan tinggi.

Data yang diperoleh bahwa tingkat pendidikan terendah dari responden adalah Sekolah Dasar sedangkan tingkat pendidikan tertinggi adalah tamat SLTA. Umumnya responden monokultur padi berpendidikan tamat Sekolah Dasar 23 responden atau 76,67 \%, yang berpendidikan SLTP yaitu 4 responden atau 13,33 \% dan responden berpendidikan SLTA sebanyak 3 orang atau 10,00\%. Sedangkan responden monokultur sapi umumnya berpendidikan tamat Sekolah Dasar 21 responden atau 70,00 \%, yang berpendidikan SLTP yaitu 6 responden atau 20,00\%, dan tamat SLTA yaitu 3 responden atau 10,00\%, sedangkan responden usahatani padi-terpadu umumnya berpendidikan sekolah Dasar 24 responden atau 80,00\%, sedangkan yang berpendidikan SLTP yaitu 5 responden atau 16,67\% dan tamat SLTA adalah 1 responden atau 3,33\%.

\section{Pengalaman Usaha}

Pengalaman adalah waktu yang telah dihabiskan oleh seseorang dalam menekuni suatu bidang pekerjaan tertentu. Pengalaman petani peternak adalah waktu yang telah dilalui oleh petani saat memulai usaha tani dan ternak sampai dengan saat survey dilakukan. Petani padi yang memiliki pengalaman yang banyak akan memiliki keterikatan secara emosional dengan kegiatan usahatani padi dan ternak, sehingga waktu yang dicurahkan akan lebih banyak dalam mengelola usahatani dan ternak dibandingkan dengan petani yang kurang pengalamannya. Dari 90 responden didapatkan rata-rata pengalaman bertani monokultur padi selama 27 tahun, monokultur sapi 17,43 tahun, petani padi + sapi terpadu masing-masing 26,90 tahun dan 14,57 tahun.

\section{Jumlah Tanggungan}

Jumlah tanggungan menunjukkan besarnya anggota keluarga yang harus dibiayai oleh kepala rumah tangga untuk kebutuhan pangan, sandang dan kebutuhan lainnya. yang dijadikan sebagai tanggungan petani dan peternak sebagai kepala keluarga adalah anak, isteri dan keluarga lain yang tinggal serumah. Hasil penelitian ini memperlihatkan bahwa rata-rata tanggungan petani baik usaha padi, sapi monokultur, dan usaha padi-sapi terpadu adalah sebanyak 3 -4 orang.

\section{Tenaga Kerja Produktif}


Tenaga kerja produktif adalah tenaga kerja dari anggota rumah tangga yang tergolong dalam usia produktif di atas sepuluh tahun (menggunakan kriteria sensus) dan terdiri dari pria, wanita dan anak-anak. Tenaga kerja produktif merupakan salah satu variabel penting yang menentukan keberhasilan produktivitas suatu usaha. Rata-rata keadaan tenaga kerja produktif keluarga petani yang menjadi responden monokultur padi dan responden monokultur sapi adalah 2-3 orang sedangkan responden usaha padi - sapi terpadu adalah sebanyak 1-2 orang.

\section{Karakteristik Usahatani Padi}

Usaha pertanian tanaman pangan dibagi dalam dua musim tanam yaitu Musim Hujan (MH) dan Musim Kemarau (MK), kedua musim ini dapat dikembangkan dengan melakukan peningkatan penggunaan lahan (Peningkatan IP), luasan lahan akan mempengaruhi produksi utama maupun limbah yang dihasilkan untuk pakan ternak sapi potong (Samsul A., dkk. 2018). Penataan fungsi lahan dan penataan jadwal tanam sesuai musim yang ada, dengan demikian lahan sawah yang terjamin sumber air pengairannya pada musim kemarau diusahakan tanam padi, sedangkan lahan sawah tadah hujan dan sawah diujung pengairan yang sulit terjangkau air pengairan diusahakan tanaman palawija atau hortikultura (sayur-sayuran).

\section{Karakteristik Usaha Tani Ternak Sapi}

Pengembangan ternak sapi potong di areal persawahan mempunyai peluang yang besar untuk dikembangkan, karena dikawasan inilah sumber pakan tersedia cukup melimpah. Selain gabah dari pertanaman padi juga dihasilkan jerami sebagai sumber pakan bagi ternak sapi, tapi sejauh ini belum banyak petani yang memanfaatkan teknologi fermentasi untuk memperkaya nilai gizinya, disamping itu penyimpanan jerami juga belum dilakukan secara baik dan efisien. Menurut Yunilas (2009), penggunaan jerami secara langsung atau sebagai pakan tunggal tidak dapat memenuhi pasokan nutrisi yang dibutuhkan ternak.

Ternak sapi yang dipelihara petani tentunya yang diharapkan adalah produktivitas berupa pertambahan berat badan harian $(\mathrm{PBBH})$ dan jumlah produksi anak yang dilahirkan pertahun. Pengelolaan sapi secara intensif dengan memperhatikan aspek pakan. Pakan yang berkualitas penting untuk pengembangan ternak. Menurut Delima., dkk., (2015), ketersediaan hijauan pakan yang cukup baik kulitas dan kuantitas adalah faktor penting 
yang harus diperhatikan untuk pengembangan ternak. Konsentrat dengan jerami padi fermentasi, manajemen kandang kolektif dan kesehatan hewan mampu meningkatkan average daily gain (Dini, 2014). Kegiatan yang dilakukan petani di lokasi penelitian adalah pemeliharaan sapi potong dengan penggunaan pakan utama berupa rumput lapangan, jerami jagung dan jerami padi tanpa fermentasi. Pemanfaatan produk samping pertanian/perkebunan sebagai bahan pakan merupakan tindakan bijaksana dalam menciptakan ketahanan pakan berbasis sumber daya lokal dan membantu mengurangi pencemaran lingkungan (Puastuti dan Susana. 2014). Pemberian pakan dilakukan secara adlibitum dengan memanfaatkan limbah pertanian dan sumberdaya lokal yang selama ini ada disekitar mereka, sehingga pada gilirannya akan menekan biaya produksi. Hal ini sejalan dengan pernyataan Novitri dkk., (2019), bahwa limbah tanaman padi dapat dijadikan pakan ternak sapi potong sehingga dapat menekan biaya pakan.

\section{Karakteristik Usahatani Padi-Ternak sapi Terpadu}

Usahatani padi menempati urutan pertama dari usaha yang petani lakukan yang dapat menghasilkan gabah sebagai produk utama dan hasil sampingan lain seperti dedak, dan jerami padi. Pada setiap musim panen tentunya diperoleh hasil yang melimpah, namun keberadaan jerami padi terkadang diabaikan oleh petani yang tidak memiliki ternak, jerami padi yang dihasilkan tidak dimanfaatkan. Malah sebaliknya jerami kemudian dibakar. Disisi lain bagi petani yang memiliki ternak peliharaan tentunya berusaha memanfaatkan jerami padi ini sebagai pakan ternak. Namun kendala yang dihadapi mereka adalah kurangnya pengetahuan dalam meningkatkan daya guna dari limbah tersebut. Sebagai contoh umumnya petani di lokasi penelitian belum mengetahui sepenuhnya cara melakukan fermentasi jerami sehingga pada musim-musim tertentu petani menghadapi masalah dalam hal ketersediaan pakan ternak.

Harapan yang ingin diperoleh dengan adanya keterpaduan usahatani padi ternak sapi adalah adanya hubungan timbal balik yang saling menguntungkan. Jika keduanya dilakukan secara terintegrasi, maka keduanya saling bersinergi dan dapat saling melengkapi satu sama lainnya (Wibawo, 2015). Keuntungan yang dapat diperoleh dari segi ekonomi menguntungkan, segi ekologi dapat menjaga kelestarian sumber daya alam, karena pupuk yang digunakan berasal dari bahan organik dimana penggunaan 10 ton akan menyediakan hara nitrogen sebesar $114 \mathrm{~kg}$, fosfor sebesar 23o kg, dan kalium sebesar $118 \mathrm{~kg}$, hal ini dapat mengurangi penggunaan dosis urea $300 \mathrm{~kg}$ menjadi $200 \mathrm{~kg} /$ ha (Suwarto. 2018). Dari segi 
sosial budaya dapat diterima dilingkungan masyarakat. Dengan konsep keterpaduan usaha diharapkan secara sistem terdapat aliran energi baik itu energi dari dalam maupun energi dari luar, sehingga ada keberlanjutan (sustainable) didalamnya. Keterpaduan usaha dapat menghasilkan diversifikasi usaha dengan adanya sinergitas yang tinggi (Harli. 2017)

\section{Analisis Perbedaan Pendapatan Usahatani Monokultur dan Terpadu terhadap Pendapatan Rumah Tangga Petani}

Berdasarkan hasil yang diperoleh bahwa sumber pendapatan rumah petani peternak dilokasi penelitian, selain berasal dari usahatani padi juga berasal dari usahatani ternak dan usaha-usaha lainnya. Untuk mendapatkan gambaran rinci mengenai pendapatan dalam rumah tangga petani diuraikan menurut sumber pendapatan dan disesuaikan dengan sistem usahatani dan ternaknya.

\section{Pendapatan Sistem Usahatani Padi Monokultur}

Hasil padi merupakan salah satu dari sumber pendapatan rumah tangga, sehingga petani yang menjadi sampel dalam penelitian ini memiliki sumber pendapatan dari usahatani padi dan pendapatan dari usaha lain yang petani lakukan. Secara rinci pendapatan yang diperoleh petani dari usahatani padi monokultur disajikan pada Tabel 1.

Tabel 1. menunjukkan bahwa tingkat pendapatan petani monokultur padi diwilayah penelitian dengan rata-rata luas lahan 0,66 ha adalah $\operatorname{Rp~9.213.550,00~per~tahun~atau~}$ sebanyak Rp 767.795 per bulan artinya pendapatan petani yang mengusahakan padi saja tingkat pendapatannya rendah dibandingkan dengan pendapatan minimum provinsi (UMP). Hasil analisis ekonomi pendapatan usahatani monokultur padi diperoleh jumlah $\mathrm{B} / \mathrm{C}$ ratio sebanyak 1,38 yang berarti jumlah $\mathrm{B} / \mathrm{C}$ melebihi satu sehingga usaha ini layak untuk diusahakan.

\section{Pendapatan Sistem Usahatani Ternak Sapi Monokultur}

Usaha ternak sapi merupakan salah suatu usaha yang dilakukan dengan tujuan untuk meningkatkan kesejahteraan petani. Petani ternak sapi mendapatkan keuntungan berupa daging, feses/kotoran sapi, maupun anak yang dilahirkan sapi. Berdasarkan hasil analisis ekonomi pendapatan yang diperoleh petani dari usaha tani ternak sapi secara monokultur. selengkapnya dapat dilihat pada Tabel 2. 
Hasil analisis ekonomi pendapatan usahatani ternak sapi monokultur memperlihatkan bahwa B/C rasio yang diperoleh adalah sebanyak 0,89, hal berarti setiap pengeluaran Rp 100 biaya, maka akan diperoleh keuntungan sebanyak 0,89 dari total penerimaan. Nilai B/C rasio yang diperoleh kurang dari satu maka usaha ini tidak layak untuk dilakukan, tingkat produktivitas sapi sangat rendah dapat disebabkan oleh ketersedian pakan kurang melimpah terutama pada musim kemarau, olehnya itu sumber pakan lain selain rumput perlu diberdayakan seperti jerami hasil padi maupun limbah lain dari usaha pertanian dan perkebunan.

Tabel 1. Pendapatan Usahatani Padi Monokultur di Kelurahan Tatae, Kec. Duampanua, Kab. Pinrang, 2008

\begin{tabular}{|c|c|c|c|}
\hline No & Uraian & Satuan & Nilai \\
\hline \multirow[t]{3}{*}{1} & Penerimaan & & \\
\hline & (1) Nilai produksi padi & Ton $(\mathrm{Rp} / \mathrm{thn}$ & 15.873.333.33 \\
\hline & Total penerimaan & & $15.873 .333,33$ \\
\hline \multirow[t]{5}{*}{2} & Biaya Tetap (Fexed cost) & & \\
\hline & - Upah buruh & HOK (Rp/thn) & $5.130 .716,67$ \\
\hline & - $\quad$ Iuran irigasi & Per (Rp/thn) & 32.833 .33 \\
\hline & - Pajak lahan & Per (Rp/thn) & 42.666 .67 \\
\hline & Total biaya tetap & & \\
\hline \multirow[t]{5}{*}{3} & Biayan variabel (variable cost) & & \\
\hline & - Benih & $\mathrm{Kg}(\mathrm{Rp} / \mathrm{thn})$ & $365.933,33$ \\
\hline & - Pupuk & $\mathrm{Kg}(\mathrm{Rp} / \mathrm{thn})$ & $858.900,00$ \\
\hline & - Pestisida/herbisida & & $228.733,33$ \\
\hline & Total biaya variable & & 1.453.566.67 \\
\hline 4 & Total biaya $(2+3)$ & & $6.659 .783,33$ \\
\hline \multirow[t]{2}{*}{5} & Pendapatan kotor $(1-(2+3))$ & & $9.213550,00$ \\
\hline & Analisis kelayakan & & \\
\hline 6 & Pajak 10 \% & & \\
\hline 7 & Pendapatan Bersih (5-6) & & $9.213 .500,00$ \\
\hline 8 & $\mathrm{~B} / \mathrm{C}(7 / 4)$ & & 1,38 \\
\hline
\end{tabular}

3. Pendapatan Sistem Usahatani Padi-Ternak Sapi Secara Terpadu

Pendapatan rumah tangga petani padi dan ternak sapi yang dilakukan secara terpadu dapat dilihat pada Tabel 3. Hasil analisis ekonomi pendapatan sistem usahatani padi-ternak sapi terpadu (Tabel 3) memperlihatkan bahwa B/C rasio yang diperoleh adalah sebanyak 1,73, hal berarti setiap pengeluaran Rp 100 biaya, maka akan diperoleh keuntungan sebanyak 1,73 dari total penerimaan. Nilai B/C rasio yang diperoleh lebih dari satu maka usaha ini layak untuk dilakukan. 
Sistem pertanian padi-ternak sapi yang dilakukan secara terpadu dapat memberikan keuntungan positif dari dua komoditi usaha tersebut. Satu sisi usaha ternak sapi dapat menghasilkan limbah kotoran/feses sedangkan tanaman padi menghasilkan jerami padi yang dapat bermanfaat sebagai pakan ternak sapi. Selain itu feses sapi dapat dimanfaatkan sebagai pupuk bagi lahan sawah. Hal ini sejalan dengan pernyataan (Adiwijoyo. 2005) bahwa untuk mempercepat peningkatan kesuburan tanah, selain dengan tanaman kacangkacangan dapat dilakukan dengan menggunakan pupuk organik yaitu kotoran ternak.

Tabel 2. Rataan Pendapatan Usahatani Ternak Sapi Monokultur di Kelurahan Tatae, Kec. Duampanua Kab. Pinrang. 2008

\begin{tabular}{|c|c|c|c|}
\hline No & Uraian & Satuan & Nilai \\
\hline \multirow[t]{5}{*}{1} & Penerimaan & & \\
\hline & (1) Produksi daging & PBBH (Rp/thn) & $11.004 .750,52$ \\
\hline & (2) Produksi anak sapi & Ekor (Rp/thn) & 3.514.683.52 \\
\hline & Nilai produksi & & \\
\hline & Total penerimaan & & $14.519 .433,52$ \\
\hline \multirow[t]{4}{*}{2} & Biaya tetap (fixed biaya) & & \\
\hline & a. Upah tenaga kerja & $\begin{array}{l}\text { HOK } \\
\text { (Rp/ha/thn) }\end{array}$ & 695.110 .29 \\
\hline & $\begin{array}{l}\text { b. Penyusutan kandang } \\
\text { c. Biaya listrik }\end{array}$ & $(\mathrm{Rp} / \mathrm{thn})$ & 33.529 .41 \\
\hline & Total biaya tetap & & 760.051 .47 \\
\hline \multirow[t]{5}{*}{3} & Biaya variabel (variable cost) & & \\
\hline & a. Pakan & (Rp/thn) & $2.024 .533,33$ \\
\hline & b. Dedak padi & (Rp/thn) & $2895.058,33$ \\
\hline & c. Vaksin/obat/vitamin & (Rp/thn) & $159.500,00$ \\
\hline & Total biaya variabel & & $5.079 .091,67$ \\
\hline 4 & Total biaya $(2+3)$ & & $7.596 .066,07$ \\
\hline \multirow[t]{2}{*}{5} & Pendapatan kotor $(1-(2+3))$ & & $7.044 .562,84$ \\
\hline & Analisis kelayakan & & \\
\hline 6 & Pajak 10 \% & & \\
\hline 7 & Pendapatan Bersih (5-6) & & $6.856 .166,86$ \\
\hline 8 & $\mathrm{~B} / \mathrm{C}(7 / 4)$ & & 0,89 \\
\hline
\end{tabular}

Hasil analisis ekonomi pendapatan sistem usahatani padi-ternak sapi terpadu memperlihatkan bahwa B/C rasio yang diperoleh adalah sebanyak 1,73, hal berarti setiap pengeluaran Rp 100 biaya, maka akan diperoleh keuntungan sebanyak 1,73 dari total penerimaan. Nilai B/C rasio yang diperoleh lebih dari satu maka usaha ini layak untuk dilakukan.

Sistem pertanian padi-ternak sapi yang dilakukan secara terpadu dapat memberikan keuntungan dari kedua usaha tersebut, baik keuntungan langsung maupun tidak langsung. 
Keuntungan yang diperoleh dengan pemanfaatan sumber daya lahan yang ada, pola tanam dengan memasukkan komoditas lain yang kompatibel dalam pola usahatani berbasis padi. Hal ini sejalan dengan pendapat Mulyadi dkk., (2013) bahwa salah satu pendekatan agribisnis yang penting diterapkan yakni kombinasi kotoran sapi dan jerami padi akan mampu memberikan manfaat bagi petani.

Tabel 3. Rataan Pendapatan Usahatani Padi-Sapi Terpadu di Kelurahan Tatae, Kec. Duampanua, Kab. Pinrang Tahun 2008

\begin{tabular}{|c|c|c|c|}
\hline No & Uraian & Satuan & Nilai \\
\hline \multirow[t]{7}{*}{1} & Penerimaan & & \\
\hline & a. Produksi jagung & Ton (Rp/thn) & $15.873 .333,33$ \\
\hline & b. Produksi jerami & Ton (Rp/thn) & $176.400,00$ \\
\hline & c. Produksi daging & PBBH (Rp/thn) & $8.836 .650,00$ \\
\hline & d. Produksi anak sapi & Ekor (Rp/thn) & $3.380 .976,95$ \\
\hline & e. Produksi feses & Ton/ekor (Rp/thn) & $121.666,67$ \\
\hline & Total penerimaan & & \\
\hline \multirow[t]{8}{*}{2} & Biaya Tetap (fixed cost) & & \\
\hline & - Upah buruh & HOK (Rp/thn) & 2.457.316,67 \\
\hline & - $\quad$ Iuran irigasi & (Rp/thn) & $32.666,67$ \\
\hline & - Pajak lahan & (Rp/thn) & $44.208,33$ \\
\hline & - Upah tenaga kerja & HOK (Rp/thn) & $1.748 .958,33$ \\
\hline & - Penyusutan kandang & (Rp/thn) & $100.800,00$ \\
\hline & - Biaya listrik & (Rp/thn) & $113.400,00$ \\
\hline & Total biaya tetap & & 4.497.350,00 \\
\hline \multirow[t]{8}{*}{3} & Biaya variabel (variabel cost) & & \\
\hline & - Benih & $\mathrm{Kg}(\mathrm{Rp} / \mathrm{thn})$ & $360.433,33$ \\
\hline & - Pupuk & $\mathrm{Kg}(\mathrm{Rp} / \mathrm{thn})$ & $834.066,67$ \\
\hline & - Pestisida & (Rp/thn) & $212.533,33$ \\
\hline & - Pakan & (Rp/thn) & $1.778 .766,67$ \\
\hline & - Pakan ternak & (Rp/thn) & $2.570 .816,67$ \\
\hline & - Vaksin/obat/vitamin & (Rp/thn) & \\
\hline & Total biaya variabel & & $5.909 .950,00$ \\
\hline 4 & Total biaya $(2+3)$ & & 10.407.300 \\
\hline \multirow[t]{2}{*}{5} & Pendapatan kotor $(1-(2+3))$ & & $17.981 .726,95$ \\
\hline & Analisis kelayakan & & \\
\hline 6 & Pajak $10 \%$ & & \\
\hline 7 & Pendapatan Bersih (5-6) & & 17.981.726,95 \\
\hline 8 & $\mathrm{~B} / \mathrm{C}(7 / 4)$ & & 1,73 \\
\hline
\end{tabular}

Hasil analisis data pendapatan usahatani padi ternak sapi monokultur diperoleh total pendapatan monokultur padi adalah sebanyak Rp 9.213.550,00 per tahun dengan jumlah biaya Rp 6.659.783,33 per tahun diperoleh BCR sebanyak 1,38 dan monokultur sapi diperoleh pendapatan sebanyak Rp 6.856.166,86 per tahun dengan biaya Rp 7.663.266,67 per 
tahun diperoleh BCR sebanyak 0,89. Usahatani padi - ternak sapi yang dilakukan secara terpadu diperoleh total pendapatan Rp 17.981.726,95 per tahun dan jumlah biaya sebanyak Rp 10.407.300,00 per tahun diperoleh BCR sebanyak 1,73.

\section{Uji Statistik Perbedaan Pendapatan Usahatani Monokultur dengan Usahatani Terpadu}

Uji statistik dilakukan untuk menganalisis secara statistik perbedaan yang ada dari pendapatan usahatani padi monokultur dengan usahatani sapi monokultur terhadap pendapatan petani. Dari hasil uji $\mathrm{T}$ uji selisih dua rata-rata untuk data berpasangan didapatkan nilai thitung $>\mathrm{t}$ tabel. Dengan pengujian dua arah cukup bukti bahwa secara signifikan untuk menyatakan adanya perbedaan pendapatan usahatani monokultur dan terpadu terhadap pendapatan rumah tangga petani $(\mathrm{P}<0,01)$.

\section{Indikator Pendapatan Rumah Tangga Petani}

Sumber pendapatan petani selain dari usahatani padi dan usahatani ternak sapi juga berasal dari usaha kebun jagung, usaha ternak kambing, usaha unggas, buruh, jualan dan usaha lain. Usaha yang dilakukan secara terpadu tentunya memiliki pengaruh terhadap pendapatan petani karena terdapat hubungan saling menguntungkan.

Hasil analisis diperoleh total pendapatan petani monokultur padi sebesar Rp 9.213.550,00 per tahun dan pendapatan monokultur sapi diperoleh total pendapatan sebesar Rp 6.659.1783,33 per tahun sedangkan pendapatan usaha padi-sapi terpadu diperoleh pendapatan sebesar Rp 17.981.726,95 per tahun. Peningkatan pendapatan petani peternak disebabkan oleh banyaknya akftivitas usaha meliputi usahatani pertanian lahan sawah, usahatani ternak sapi, usaha kebun jagung, usaha ternak kambing, usaha unggas, jualan, buruh, dan lain-lain dilakukan secara terpadu dalam sebuah mekanisme sistem.

Berdasarkan keterangan yang diperoleh bahwa status pekerjaan petani/peternak berpengaruh terhadap pendapatan yang diperoleh, dimana ada petani menganggap bahwa usahatani padi atau sapi dianggap sebagai usaha sampingan semata, sementara ada usaha lain yang dianggap sebagai usaha pokok. Menurut informasi yang diperoleh peneliti bahwa usaha dianggap pokok bilamana setiap hari bisa menghasilkan uang dan dapat digunakan untuk keperluan keseharian petani, sehingga menganggap usaha lain seperti jualan, buruh merupakan pekerjaan pokok, akibatnya waktu yang dicurahkan untuk usahatani padi berkurang dan akan berdampak pada produktivitas usahanya. 
Faktor lain yang menyebabkan adanya peningkatan pendapatan petani ternak sapi adalah adanya input dari usaha lain seperti usaha kebun jagung yang dapat menghasilkan jerami jagung yang merupakan input pakan sapi, akibatnya petani tidak mengeluarkan biaya untuk membeli jerami. Menurut Lukiwati., et al. (2019), salah satu bentuk sistem integrasi jagung pulut-sapi dimana jagung menghasilkan brangkasan untuk pakan sapi, sebaliknya sapi menghasilkan pupuk kandang untuk jagung Sementara itu analisis usaha ternak kambing dan unggas memperlihatkan adanya pendapatan minus yang diperoleh petani peternak, namun melalui usahatani yang dilakukan secara terpadu maka usaha tersebut dapat direduksi usaha lain, sehingga pendapatan rumah tangga petani akan menguntungkan. Hal ini sejalan dengan pendapat Yuliani (2014) bahwa teknologi integrasi padi-ternak dapat memperbaiki tambahan pendapatan bagi petani dalam kondisi sinergisme dalam pemanfaatan input usahatani dari sumber tersedia secara optimal.

Berdasarkan penjelasan diatas membuktikan bahwa semakin banyak aktivitas usaha yang dilakukan secara terpadu, maka semakin tinggi pengaruh terhadap pendapatan, satu sisi usaha lain menghasilkan output yang menjadi input bagi usaha lain, hal ini tentunya berdampak pada pengurangan biaya yang dikeluarkan oleh petani.

\section{Keberlanjutan (Sustainable) Kegiatan Pertanian Terpadu}

Keberlanjutan dalam mengelola suatu sistem pertanian menjadi keberlanjutan memenuhi aspek kelayakan meliputi; kelayakan secara ekonomis, bernuansa dan bersahabat dengan ekologi, diterima secara sosial, dan kepantasan secara budaya, pendekatan sistem dan holistic (system and holistic approach). Keberlanjutan pertanian terpadu tentunya tidak terlepas dari kelima hal tersebut diatas namun implementasi pembangunan pertanian yang berkelanjutan khususnya di Indonesia tidaklah mudah karena dihadapkan pada banyak kendala, antara lain kendala sumber daya manusia: rata-rata tingkat pendidikan petani relatif rendah; kondisi kesehatan petani kurang baik; produktivitas masih rendah; dan kurangnya motivasi untuk maju. Selanjutnya kendala aplikasi teknologi dimana praktek-praktek usahatani yang mengancam kerusakan lingkungan antara lain penggunaan pestisida untuk membasmi hama dan penyakit tanaman. Faktor lain yang mendukung kegiatan usahatani adalah tenaga kerja yang digunakan petani, umumnya tingkat pendidikan petani kurang baik, produktivitas kerja masih rendah, dan kurangnya motivasi untuk maju. 


\section{KESIMPULAN}

Berdasarkan hasil pembahasan diatas maka dapat disimpulkan sebagai berikut:

1. Pertanian terpadu yang dipraktekkan di Kelurahan Tatae, Kecamatan Duampanua dipengaruhi oleh keragaman aktivitas yang tinggi yakni pertanian tanaman pangan, peternakan sapi, usaha kebun, usaha kambing, usaha unggas, dan usaha lain yang memberi kontribusi terhadap peningkatan pendapatan petani.

2. Hasil penelitian menunjukkan bahwa pendapatan yang diperoleh petani yang menerapkan pertanian monokultur padi adalah Rp 9.213.550,00 per tahun dengan B/C Ratio sebesar 1,38, sedangkan petani monokultur sapi diperoleh pendapatan Rp 6.856.166,66 per tahun dengan B/C Ratio sebesar 0,89 dan petani yang menerapkan usahatani padi-sapi secara terpadu diperoleh pendapatan Rp 17.981.726,95 per tahun dengan nilai B/C Ratio sebesar 1,73.

3. Adanya saling keterkaitan antara subsistem melalui aliran input-output antara tanaman dan ternak, maka usahatani padi dan ternak sapi ditambah dengan usaha-usaha lain yang dilakukan secara terpadu oleh petani di Kelurahan Tatae, Kecamatan Duampanua, Kabupaten Pinrang.

\section{DAFTAR PUSTAKA}

Adiwijoyo, S. 2005. Reformasi Bidang Pertanian. Pakar (Pusat Kajian Reformasi) Jakarta

Delima., M. Karim., A., dan Yunus., M. 2015. Kajian potensi produksi hijauan pakan pada lahan eksisting dan potensial untuk meningkatkan populasi ternak ruminansia di Kabupaten Aceh Besar. Jurnal Agripet. 15 (1), 33-40.

Dini. 2014. Sistem integrasi padi ternak untuk mewujudkan kedaulatan pangan. Jurnal Agroteknologi , 4 (2), 15-26.

Harli. 2017. Sistem integrasi tanaman-ternak kambing untuk produksi kakao yang resilien. Jurnal Agrovital, 2(1), 1-7

Hasan dan Safaruddin. 2012. Pengaruh Sistem Integrasi Padi Ternak (SIPT) terhadap Peningkatan Pendapatan Petani dan Dampaknya Terhadap Pengembangan Wilayah di Kabupaten Serdang Bedagai. Jurnal Ekonom, 15 (4), 163-172.

Indira., 2017. Integrated Crop-livestok Farming System For the Sustainable Livestok. Production International Journal of Innovative Research and Advanced Studies (IJIRAS) 4 (6), 117-120.

Kusnadi., U. 2008. Inovasi Teknologi Peternakan dalam Integrasi Tanaman Ternak untuk Menunjang Swasembada Daging Sapi. Jurnal Pengembangan Inovasi Pertanian. 1 (3), 189-205

Lukiwati., Kusmiyati, Yafizham, dan Anwar., (2019). Improvement of Plant Growth and Production of Waxy Corn With Organic-NP Enriched Manure and inorganik Fertilizer in Sragen of Central Java Indonesia. International Conference on Food and Technology. IOP Conf. Series: Earth and Enviromental Science 292 (2019): 012056. 
Mulyadi., Wihardjaka dan Setiyanto., 2013. Pengelolaan Biogas dan Integrasi Tanaman Pangan dan Ternak Sapi pada Lahan Sawah Tadah Hujan. Prosiding Expose dan Seminar Nasional Inovasi Pertanian Ramah Lingkungan, 685-693.

Novitri., K, Edi F., dan Denni D., 2019. Sistem usaha tani integrasi padi dan sapi meningkatkan pendapatan petani di Kelurahan Kedui Kabupaten Seluma Propinsi Bengkulu. Jurnal Ilmiah Agribisnis Perikanan, 12 (1), 64-69.

Wisri., P dan Susana IWR. 2014. Potensi dan Pemanfaatan Kulit Buah Kakao Sebagai Pakan Alternatif Ternak Ruminansia. Balai Penelitian Ternak, Bogor

Samsul., A., Limi., M.A., Zani., M., dan Salamah., 2018. Analisis potensi dan kelayakan usahatani sistem integrasi padi ternak (Studi Kasus di Desa Silea Jaya Kecamatan Buke Kabupaten Konawe Selatan). Jurnal Ilmu dan Teknologi Peternakan Tropis, 6 (3), 375-381.

Suwarto. 2018. Reduction of urea fertilize uses throught application of livestock manure in an integrated farming system of maizeang cattle. Journal of Tropical Crop Science. 5 (1), 18-24.

Usman., Batseba., Tiro dan Dominanto. 2017. Model integrasi sapi potong dengan padi sawah mampu meningkatkan pendapatan petani di Papua. Seminar Nasional Peternakan 3, Universitas Hasanuddin Makassar, Paper 181-188.

Wachirapkom., C. Pilachai., K., Wanapat., M., Pakdee., P., Cherdthetong., A., 2016. Effect of grown corn cobs as a fiber source in total mixed ration on feed intake, milk yield and milk composition in tropical lactating crossbred holstein cows. Animal Nutrition, 2:334 $-338$.

Wibawo. 2015. Sistem Pertanian Bioindustri yang Berkelanjutan Berbasis Integrasi Padi-Sapi BPTP. Bengkulu.

Yunilas. 2009. Karya Ilmiah. Bioteknologi Jerami Padi Melalui Fermentasi Sebagai Bahan Pakan Ternak Ruminansia. Fakultas Pertanian, Universitas Sumatera Utara, Medan. Repository.Usu.Ac.Id/Bitstream/Handle/805/09E01417.Pdf;.

Yuliani. 2014. Sistem integrasi padi ternak untuk mewujudkan kedaulatan pangan. Jurnal Agroteknologi 4 (2), 15-20. 